\title{
HOW EFFECTIVE IS TAX POLICY IN ATTRACTING FOREIGN DIRECT INVESTMENTS IN TRANSITION COUNTRIES?
}

\section{Silajdzic, S., Mehic, E.}

Sabina Silajdzic / University of Sarajevo, School of Economics and Business, Department of Economics, Trgoslobodjenja - Alija Izetbegovic 1, Sarajevo, Bosnia and Herzegovina. Email: sabina.silajdzic@efsa.unsa.ba

Eldin Mehic / University of Sarajevo, School of Economics and Business, Department of Economics, Trgoslobodjenja - Alija Izetbegovic 1, Sarajevo, Bosnia and Herzegovina. Email: eldin.mehic@efsa.unsa.ba

\section{Abstract}

Foreign Direct Investments (FDI) has been considered an important source of economic growth and technological development in transition economies. The previous empirical literature has shown that FDI promote economic growth via complementary effects on domestic investments, increases in productivity and overall economic efficiency, giving rise to an increasing interest in understanding the key determinants of FDI. Apart from traditional FDI determinants, favourable tax policy has been considered an important factor influencing MNCs' location decisions. The goal of this paper is to investigate the impact of corporate income tax on FDI in the context of less advanced transition economies and to analyse whether the tax effect is conditional on the level of economic development. A small number of studies exist analysing the importance of tax policy regime in attracting FDI covering SouthEast European countries. In this study, we rely on panel gravity econometric framework and examine the impact of tax policy on FDI using bilateral FDI flows between 8 home and 8 South East Europe host countries in the period 2000-2018. We estimate the regression using Prais-Winsten correlated panels corrected standard errors PSCE method to obtain robust estimates of individual effects in the presence of heteroscedasticity and serial correlation. The seven SEE host countries included in the sample are considered of similar economic structures and institutional transformation, which seems important in analysing tax policy effectiveness and minimising biases associated with econometric modelling of FDI determinants. Finally, we study this relationship in an integrated framework considering traditional gravity forces as well as a number of additional FDI determinants, including institutional factors. We show that, although tax policy seems an important determinant of FDI, its effects seem to be conditional on the level of technological development. Given these findings, reducing corporate income tax may be considered an effective tool in promoting FDI, which seems to be of particular importance for less developed transition economies. The results are robust to different model specifications and consideration of endogeneity.

Implications for Central European audience: The direct implications of this research for business policymakers in CEE include the need to revise and optimise the levels of corporate income tax and incorporate this specific policy instrument in FDI strategies. In particular, the results of this research indicate that tax cuts have been more effective in attracting FDI in countries that are at a lower level of technological sophistication. The managers could seek 
to size the investment opportunity related to possible further corporate income tax cuts in the group of least developed CEE amid the economic rationale for tax policy competition among these countries.

Keywords: FDI; corporate income tax; tax incentives; gravity model; transition economies JEL Classification: C23, E62, F21

\section{Introduction}

Transition economies' integrative policy efforts aim to attract foreign direct investments (FDI) to enhance competitiveness and promote economic growth. FDI is considered as an important factor that can promote technological development, induce effective industrial restructuring, increase employment opportunities and promote the creation of new, supposedly more sophisticated jobs amid the specific context of emerging market economies (Alfaro et al., 2004; Borensztein et al., 1998; De Mello, 1999). Especially, countries in transition are found to benefit from FDI through rising productivity (Bijsterbosch \& Kolasa, 2010; Damijan et al., 2003) and positively affecting economic growth (Silajdžić \& Mehić, 2012, 2016). In view of well-substantiated empirical evidence suggesting the positive impact of FDI on host economy performance, the key question in FDI related empirical literature became one of the key factors influencing location decisions of Multinational Enterprises (MNCs). Apart from traditional determinants of FDI such as market size, labour costs and productivity, industrial structure and infrastructure endowment (Carstensen \& Toubal, 2004), the institutional and policy factors have increasingly been found to play a prominent role in attracting FDI in transition economies (Bevan \& Estrin, 2004; Estrin \& Uvalic, 2014; Silajdžić \& Mehić, 2012).

However, transition literature related to FDI determinants seems to suggest that policy and institutional factors are more important in countries that are at the lower level of economic and supposedly technological development (Bellak et al., 2010; Demekas et al., 2007). This is to say that institutional and policy factors may compensate for deficient industrial structures and production-related human and material infrastructure (albeit in certain sectors in which knowledge-related infrastructure remain of lesser importance). Constructing a favourable regulatory and policy framework to attract FDI has been put at the forefront of discussion in more recent literature on FDI (Singhania \& Saini, 2018; Silajdžić \& Mehić, 2012). In particular, formulating policy measures that affect MNCs' costs of transiting to a new market and operating costs have been given particular attention in recent years (Rădulescu \& Druica, 2014).

Among many policy initiatives to attract FDI, tax policy has been considered an important direct policy instrument. Tax policy and low corporate income tax, in particular, has been considered a viable policy option that is easy to administer and under direct government control. In this vein, all European transition economies, regardless of their level of development, have substantially reduced their corporate income tax over the course of transition (see Bellak et al., 2010). The tax policy trade-off(s) in terms of decreasing public revenues and preferential treatment of foreign investor(s) has been justified on the ground of positive direct and spillover effects associated with FDI in transition economies. A number of 
studies have investigated the impact of corporate income tax in transition economies (Bellak et al., 2009; Demekas et al., 2005). Both studies find the significant and negative impact of corporate income tax on FDI. It is worth noting that the results of these studies suggest that the impact of taxation on FDI is dependent on factors that are assumed to depict the differences in the levels of technological prowess and absorptive capacity of the host economy. Precisely, while Bellak et al. (2009) suggest that the economic significance of reduced taxation (i.e., effective average tax rate EAFT) is conditional on material infrastructure endowment, i.e., transport infrastructure, telecommunications, electricity supply, Demekas et al.'s (2005) study finds that statutory corporate income tax turns to be insignificant for the group of countries above the estimated threshold level of FDI. The results of their study seemingly imply that tax policy may be ineffective in attracting FDI for the higher FDI recipient countries. The GMM estimator, however, reveals the opposite results, suggesting counter-intuitively that lower tax rates are more beneficial for countries above the estimated threshold level of inward FDI (i.e., 12.5\% of GDP). The latter result is of particular importance, as it reveals an ambiguity in comprehending the impact of corporate income tax on FDI inflows in transition economies. While further research has deepened our understanding of the role of taxation relying on the group of CEE countries (Bellak et al., 2009; Wolff, 2007), the countries of South-East Europe (SEECs) have not been comprehensively covered in previous econometric analysis. The aforementioned study by Demekas et al. (2005) integrates SEECs countries in empirical analysis. The cross-section regressions and the panel framework used in this analysis reveal important statistical inferences that are related to bilateral FDI flows between the 14 developed home EU countries and the 24 host country transition economies. However, the ambiguity that is related to the conditional impact of the statutory tax rate, suggested by their findings, needs to be further researched.

Following past empirical research, in this analysis, we firstly emphasise the inconclusive evidence and vague policy implications related to the obtained mixed results with respect to the tax rate effects in Demekas et al.'s (2005) study. In addition, a meta-regression analysis conducted by Heimberger (2021) renders further support to inconclusive evidence on the impact of corporate income tax on FDI. In particular, the results of this study clearly reveal that both data and specification choices systematically affect the results obtained by the literature, including econometric estimation strategy and model specification. The results point to the relevance of accounting for specific country characteristics. From an FDI policy perspective, the ambiguity is particularly relevant for countries that have introduced substantially low corporate income tax and engaged in forceful tax policy competition, such as is the case of the group of SEECs (see Bellak et al., 2010). We extend this work by focusing on SEE countries in more recent periods i.e., 2000-2018, the period in which substantial tax cuts have been introduced and the period characterised by a substantial reduction in FDI flows in the wake of financial crises and economic recession. The FDI inflows to the region have not recovered since. In such a specific contextual framework, we seek to explain whether tax policy efforts pay off. The results of this study are particularly important since they consider the specific context of SEEC, the group of least developed transition economies, that face important policy trade-offs associated with declining government revenues following provision of diverse fiscal privileges and preferential treatment of foreign companies, including reduction(s) incorporate income tax over the course of transition. 
Secondly, we emphasise that investigating the impact of different tax policy choices seem particularly relevant for the SEE countries, that rank substantially lower across diverse transition indicators, and especially in terms of institutional quality indicators compared to a more advanced group of CEECs (Bellak et al., 2010; Estrin \& Uvalic, 2014; Silajdžić \& Mehić, 2012). We posit that policy efforts could compensate for underdeveloped markets and inferior technological infrastructure among countries that have similar economic structures and have embarked on a similar pattern of transition. Previous research has highlighted the importance of distinctive characteristics of SEECs countries that need to be considered. The economies of South-East Europe are found to attract a substantially lower amount of FDI compared to CEE countries, even after controlling for gravity forces, institutional and policy factor differences (Estrin \& Uvalic, 2014). We extend previous work by differentiating between the two supposedly different groups of host transition economies, namely the group of CEECs and the group of SEECs countries. In view of the persistent differences across the two groups of transition economies, the fixed effect models used in other studies examining the impact of corporate income tax on FDI in a bilateral framework that cover Central and Eastern European Economies (CEECs) (Bellak et al., 2009) inhibit conclusions on the importance of tax policy among the SEE countries. Moreover, the potential merits of substantial tax cuts among SEECs become particularly relevant considering the public resource constraints and limited fiscal capability of SEECs' governments.

Therefore, the purpose of this paper is to model the impact of corporate tax rates on FDI inward flows in SEE countries, on which we have scarce empirical evidence. The goal of this paper is to investigate the impact of corporate income tax on FDI in the context of less advanced transition economies of SEE, and in particular, to analyse whether or not the tax effect is conditional on the level of economic development. First, we aim to investigate whether recent corporate income tax cuts among SEE countries do pay off in terms of how successful these policy efforts have been in attracting FDI. Second, we aim to investigate whether these policy efforts are worthy regardless of the country's level of development and irrespective of its technological prowess. This study differs from previous studies since it covers a longer period and examines both the impact of statutory corporate income tax as well as relative tax rates on FDI (Bénassy-Quéré et al., 2003) for the group of SEE countries. We rely on gravity econometric framework and examine the impact of tax policy on FDI using bilateral FDI flows between 8 home (major trading partners among EU-15 member states that account for over $70 \%$ of total inward FDI in SEE countries) and 8 host countries (i.e., Albania, Bosnia and Herzegovina, Croatia, Serbia, Romania, Bulgaria and Montenegro) in the period 2000-2015. The seven SEE host countries included in the sample are considered to be of similar economic structures and institutional transformation, which seems important in analysing tax policy effectiveness and minimising biases associated with econometric modelling of FDI determinants (see Silajdžić \& Mehić, 2016). Finally, we study this relationship in an integrated framework considering traditional gravity forces as well as several additional FDI determinants, including institutional factors. We show that although tax policy seems an important determinant of FDI, its effect seems to be conditional on the level of overall economic and supposedly technological development.

This paper is structured as follows: In the next section, we provide a brief theoretical framework and elaborate on traditional factors explaining differences in FDI inflows. We then briefly review theoretical and empirical findings underlying the importance of institutional and policy factors, apart from gravity forces, and consider empirical findings related to the role of 
tax policy in understanding bilateral FDI flows. The third and fourth section explains the methodology used for examining the impact of corporate tax rates on FDI in SEE region and discusses the results. The conclusions and policy implications follow.

\section{Determinants of FDI and the role of taxation in transition economies}

The literature on FDI determinants is vast. Most authors rely on Dunning's (1988) conceptual framework focusing on motives of FDI by analysing reasons and strategies of multinational corporations to invest abroad. In terms of motives for FDI, he classified MNEs as market seekers, natural resource seekers and efficiency seekers. Location determinants of FDI are principally derived from Dunning's work on the motives of MNC to internationalise their business activities by seeking advantages of internalisation. Traditional FDI determinants include market size, cost of labour and technological prowess of host countries. The role of institutions and specific policy frameworks has been considered an important factor in attracting FDI in recent literature. In particular, Dunning (1993) emphasises the importance of institutions and other location-specific advantages in attracting FDI. According to Dunning, location-specific advantages can be classified into four categories as follows: natural resource advantages, economic environment advantages, political power, policy and legal environment and cultural and social advantages. Considering the first group, MNEs can benefit from the distribution of natural and produced resources like energy, geographical location and raw materials. As far as the economic environment advantages, MNEs can benefit from lower prices of inputs, intermediate goods, low cost of skilled labour, market size, low communication and transportation costs, along with centralised research and development production. Also, economic advantages include trade barriers (quotas and tariffs) as investment incentives. Cultural and social advantages like language similarities, distance proximity between home and host country and societal advantages like education can contribute for MNEs to be better off. Moreover, political stability, institutional framework, sustainable economy, along with favourable FDI policies, can bring advantage to investment activities of MNEs.

When considering the importance of taxation, it's noteworthy that taxation affects the cost structures of multinational investment and that it affects MNC's investment decisions across all three types of FDI. In the long run, the corporate tax rate may have an impact on output prices and wages. For instance, a study by Merz et al. (2017) finds a negative effect of host country corporate income taxes on the probability of choosing a particular host location in the specific context of investment in the financial sector. Given the reductions in labour and capital inputs used in the corporate sector due to the corporate tax effect, wages of the labour force tend to decline in the long run. Such changes in the corporate sector might not cause a shift of labour to the non-corporate sector, which depends on the elasticity of substitution in the production of factors in both sectors (Hyman, 2014).

MNEs' decisions on location in CEE countries are influenced by a different set of measures proposed by governments. In order to form attractive location factors for future investors, governments offer fiscal and non-fiscal incentives. In this paper, the accent is on corporate taxation because of its possible impact on location decisions and FDI's profitability. Taxation is aimed at encouraging investment and inducing economic growth, while foreign direct investment with the usage of an appropriate policy framework is assumed to promote 
economic development, principally by enhancing technological upgrading of industries and promoting regional competition.

Considering the relatively low investment potential of SEEC countries, tax policy is generally perceived as an important determinant of FDI that could compensate for limited market size and structure and an underdeveloped institutional framework. The role of taxation in transition economies as an FDI determinant has been investigated by Bellak et al. (2009). They used the gravity model with the application of effective average tax rates on the bilateral level in order to explain FDI flows to Central and Eastern European countries. Their study suggests that FDI is positively related to home and host market size but inversely related to unit labour costs and a distance between home and host countries. Tax rate measured as EATR has been found to adversely affect FDI. An additional study, relying on a similar econometric framework and referring to the same bilateral set of countries, has been conducted by Bellak et al. (2009). The new empirical evidence suggests that while EFTA is significantly negatively related to FDI inflows, its marginal effect is conditional on the level of production-related material infrastructure, indicating that tax policy could compensate for the lower levels of infrastructure development. Similar findings are obtained by Bénassy-Quéré et al. (2000) or Djankov et al. (2010). The notable exception is the study conducted by Kersan-Škabić (2015), which considers the countries of the SEE region solely, and renders support to the significance of corporate tax rate to attract FDI in the specific context of SEE countries. The study suggests the negative and significant impact of STR on FDI when measured as inward FDI stock.

Other studies covering transition economies are mainly studies that integrate the group of Central and Eastern European countries (CEECs) and investigate the impact of tax differentials on location decisions of MNCs in the context of enlarged EU. For instance, Wolff (2007) investigates the impact of taxes and market size on FDI among EU countries. The regression without the time and country controls show that host corporate tax reduces FDI inflows, especially investments in equity. However, after including time and country controls, regression results show insignificant coefficients for home and host tax rates and their influence on equity FDI. Yet, empirical findings for the sample exhibit different results. The results show that even after controlling for country dummies, the statutory tax rate appears to be significant for the allocation of profits across CEE countries. The results of this study point to the importance of taking into account differences in the economic structures of the host country that seemingly cannot be observed by country-specific effects, such that differences in sample characteristics may yield different and inconclusive results. Structural differences among transition economies are carefully considered in this study which investigates the role of taxation while relying on the sample of SEECs.

In a similar vein, Hansson and Olofsdotter (2010) empirically estimated the effects of corporate taxation and agglomeration process on bilateral FDI stock and flows within the old and new EU member states. The study covers $27 \mathrm{EU}$ member states in the period between 1995 and 2006. Hansson and Olofsdotter find that FDI flows of new member countries are affected by tax differentials. Moreover, the decision of how much to invest is more sensitive to tax differentials than the decision of where to invest. Similar to the analysis of Razin and Sadka (2006), authors follow the model of two-fold decisions based on questions whether to invest and how much to invest. Thus, one of the findings shows a big discrepancy of factors determining FDI between the new and the old EU members (Razin \& Sadka, 2006). The 
results of these studies point to the importance of incorporating relative tax rates in the econometric framework that we take into account in this study. Some countries may face alterations in market potentials, whereas tax differentials can compensate for disadvantages in market potential through lower STR (Bénassy-Quéré et al., 2003).

Considering the consistency in the empirical findings among transition economies, it's worth emphasising that the tax system plays an important role in every country, especially in transition economies. Taxation is aimed at encouraging investment and inducing economic growth, while foreign direct investment with the usage of an appropriate policy framework is assumed to promote economic development, principally by enhancing technological upgrading of industries and promoting regional competition. According to OECD (2016a) data, transition countries have decreased corporate tax rates in recent years (2000-2015). It is evident that Balkan countries have the lowest tax rates comparing to not only to developed EU countries but also compared to average tax rates among CEE countries. A study by Bellak et al. (2010) clearly indicates that there is not much policy scope left for lowering tax rates on the proceeds of FDI among the SEECs. Most of the SEE countries have a flat corporate tax system and the lowest in Europe. The lowest tax rates belong to Bosnia and Herzegovina, Macedonia, Albania and Bulgaria, while Croatia, Serbia, and Romania have the highest rates among the SEE group of countries.

In particular, FDI-related policy measures seem an important rivalry tool, especially in the context of economies characterised by similar economic structures and patterns of economic transformation, such as is the case of SEE transition countries. In view of these similarities, there is increasing interest among policymakers in creating a favourable business environment and the use of available policy stances in promoting FDI in these countries. The increasing awareness of the importance of FDI among government officials has resulted in the development of FDI-specific policies and institutional settings depicted in OECD FDI institutional framework indices (OECD, 2016b). Essentially, tax policy measures have been used as a complementary tool in creating a favourable environment for foreign investors. In recent years SEE countries have reduced corporate income tax and integrated a number of tax policy incentives.

In an attempt to promote a differentiated and attractive FDI environment, SEE countries have put their tax-related revenues and local firms at odds in view of the expected long term economic benefits associated with FDI related positive externalities. In view of this, the critical question becomes one of the effectiveness of these tax policy measures in attracting FDI. The purpose of this paper is to examine the relevance of tax policy in promoting FDI in SEE. Specifically, we investigate the impact of corporate income tax on FDI in SEE. Lower-income tax is by and large found to be an important determinant of FDI in countries at the lower level of technological development and industrial diversification, as is the case of SEE countries.

\section{Empirical analysis}

\subsection{The model}

The empirical analysis is based on a panel gravity model. We use the Ordinary Least Squares (OLS) econometric framework to analyse the determinants of FDI in transition countries. The study encompasses eight transitions SEE host countries j: Albania, Bosnia and Herzegovina, Bulgaria, Croatia, Macedonia, Montenegro, Romania and Serbia and eight major trade 
partners denoted as home countries i: Austria, Germany, Italy, Netherlands, France, Slovenia, Switzerland and Turkey. The data covers bilateral FDI flows between host and home countries in the period between 2000 and 2018. The data on bilateral FDI flows prior to 2000 are not available for the SEE sample of countries.

We developed a baseline specification:

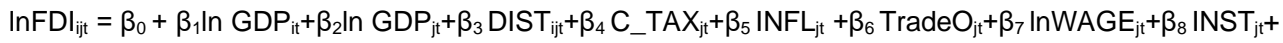
$\beta_{9} \log \mathrm{GDPpc}_{t}+$ Country + Time $+\varepsilon_{\mathrm{i}}$,

where the dependent variable FDlijt indicates bilateral FDI flows between the selected host and home countries expressed as the logarithm of FDI stock in period t; InGDPit indicates logarithm of the gross domestic product of a home country $i$ in period $t$; InGDPjt indicates a logarithm of the gross domestic product of a host country $j$ in period $t$; DISTijt indicates the distance between home and host countries; C_TAXjt indicates corporate tax of a host country $\mathrm{j}$ in period $\mathrm{t}$; INFLjt indicates inflation rate of a host country $\mathrm{j}$ in a period $\mathrm{t}$; TradeOjt indicates openness to trade of a host countryand it is expressed as a share of total trade to GDP; InWAGEjt indicates a relative cost of labour of a host country and is expressed as an average nominal wage in the manufacturing sector over GDP per capita following Bevan and Estrin (2004); logGDPpct indicated differences in levels of per capita income between home and host country, whereINSTjt captures a range of institutional quality indicators developed by the World Bank (i.e. World Bank good governance indicators) considered important for wellfunctioning of national economies including: CORUPTjti indicates the level of corruption in a host country $\mathrm{j}$ in period $\mathrm{t}$ and RoLawjt indicates the rule of law in a host country $\mathrm{j}$ in period $\mathrm{t}$; Country variable captures the specific effects of each individual bilateral FDI transaction between host and home countries, while Time captures time specific effects and $\varepsilon$ i indicates the error term.

Following the gravity model assumptions, we presuppose that FDI stock is positively related to the GDP of host and home countries as the size of the economy and negatively related to the distance between host and home countries. Importantly, we postulate a negative relationship between corporate tax rate and FDI.

Specifically, we test the following main research hypothesis:

H1: The level of corporate income tax is significantly adversely related to FDI, pointing to the effectiveness of taxation policy in attracting FDI in SEECs.

H2: The relative corporate income tax rate is significantly positively related to FDI, suggesting the importance of comprehending tax differentials between home and host country when examining tax policy effects.

H3: The marginal effect of corporate income tax is conditional on a host country level of development, such that profound differences in economic structures and levels of development between home and host countries, depicted in per capita income differences, explain the increasing marginal effect of corporate income tax on FDI.

To test hypothesis 2 and 3 we have also developed an alternative model specification in which we replaced C_TAXjt variable with C_TaxDijt which indicates the difference of tax rates between home country $i$ and host country $\mathrm{j}$ in a period $t$, and augmented the baseline specification with Interaction term (C_Tax ${ }^{\star}$ GDPpc Difference), which captures the effect of 
corporate income tax conditional on the differences in the levels of GDP per capita between home and host countries. The alternative model specifications are as follows:

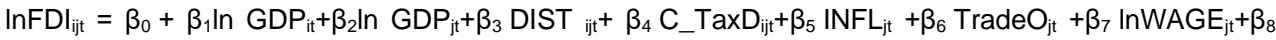
INST $_{j t}+\beta_{9} \log$ GDPpc $_{\mathrm{t}}+$ Country + Time $+\varepsilon_{\mathrm{i}}$

$\operatorname{lnFDI} I_{\mathrm{ijt}}=\beta_{0}+\beta_{1} \ln \mathrm{GDP}_{\mathrm{it}}+\beta_{2} \operatorname{In} \mathrm{GDP}_{\mathrm{jt}}+\beta_{3} \mathrm{DIST}_{\mathrm{ijt}}+\beta_{4} \mathrm{C}_{-} \mathrm{Tax}_{\mathrm{ijt}}+\beta_{5} \mathrm{INFL}_{\mathrm{jt}}+\beta_{6} \operatorname{TradeO}_{\mathrm{jt}}+\beta_{7} \operatorname{InWAGE}_{\mathrm{jt}}+\beta_{8}$ $\mathrm{INST}_{\mathrm{jt}}+\beta_{9} \log \mathrm{GDPpc}_{\mathrm{t}+} \beta_{10}$ Interaction $_{\mathrm{t}}+$ Country + Time $+\varepsilon_{\mathrm{i}}$.

\subsection{Data and variables}

For this research, we use the log of FDI stock between host and home countries denoted in EUR. The advantage of the FDI stock variable is that its value cannot be negative and avoids time anomalies, unlike FDI flows which null or negative values may affect the functional form of gravity equation. Thus, yearly FDI flows between transition countries vary with huge fluctuations resulting from the process of privatisation that may not capture the effect of individual explanatory variables. The Vienna Institute for International Economic studies is the source of data for bilateral FDI stock (WIIW).

As a proxy for the market size, we have included GDP host denoted as GDPi and GDP home denoted as GDPj. Other control variables include distance denoted as DIST, wage denoted as WAGEj, inflation rate denoted as INFLj, and trade openness as TradeOj. All these variables are found to be significant in the number of other studies related to foreign direct investment (Bevan \& Estrin, 2004).

The proxy variable GDP home is used to reflect on the economic power of investors. Two outcomes can be expected considering the home country market size. The first result is that the source country can decide to place production on a single plant to utilise economies of scale and export. On the contrary, economies of scale can encourage source countries to set production abroad closer to the markets by investing and establishing multinational companies (Bevan \& Estrin, 2004). A vast majority of empirical studies find a positive relationship between home GDP and FDI in transition economies (Resmini, 2000). The host GDP variable in our model serves as a proxy for market size, which is expected to have a positive effect on FDI. Market size is a location-specific advantage for the host country as the broader market appeals to the placement of new products and affects investors' decisions. That also depends on the dynamics of the market and its overall size (Resmini, 2000).

In our study, distance is a proxy for the geographical distance between capital cities of a home and host countries. We used the CEPII database as a source. Distance is a timeinvariant variable that is constant in its value. It is usually used to reflect trade costs (Carstensen \& Toubal, 2004). Moreover, a distance can be used as a proxy for cultural differences, language, transportation and operating costs (Brenton et al., 1999). According to Hansson and Olofsdotter (2010), distance has a negative effect on FDI. They also emphasise its ambiguity because, besides geographical distance, it is also used to reflect trade costs. Another prospect for using distance is that it may reflect the cost of acquiring information or the obstacles in managing distant affiliates (Hansson \& Olofsdotter, 2010).

Previous empirical studies show that labour cost has neither statistically significant nor significantly adverse effect on FDI. Labour costs play a crucial role in labour-intensive industries as lower labour costs tend to attract more investment. Studies suggest a twofold effect of labour costs. Carstensen and Toubal (2004) found a significantly negative effect of 
labour costs on FDI inflows which is in line with findings of Bevan and Estrin (2004) and Resmini (2000). On the contrary, Bénassy-Quéré et al. (2005) found a statistically insignificant but positive effect of labour costs on FDI. This is why in this study, we measure labour cost relative to labour productivity, following Bevan and Estrin (2004). Specifically, we use a unitless measure of labour cost so that we relate it to the labour productivity of the host country. Our proxy for labour cost is the ratio between average gross monthly wages in the manufacturing sector over the GDP per capita, in the logarithm form. In view of this, we assume that relative labour costs will have a positive impact on FDI, depicting relative productivity of labour. We use UNECE as a source for labour cost data.

In most empirical studies, inflation is used to reflect on the macroeconomic stability of a host economy. It also reflects on the prudence of fiscal policy in general. Investors will be attracted by a low inflation rate that implies stable macroeconomic conditions for low-risk investment. Unexpectedly, in his empirical study, Sato (2012) found a positive impact of inflation on FDI value, whereas he justifies it with the rise in prices as the economy expands vigorously. $\mathrm{He}$ also reflects that positive sign can explain the positive future economic prospects of the host country that followed an increase in FDI inflows. However, a high inflation rate can destabilise the economy and deter future investments. Our expectation in this analysis is that a low inflation rate will cause FDI to increase. The source of this data is the IMF database.

The emphasis of this empirical investigation is on the estimation of the effect of the corporate income tax rate on FDI. We include two variables: corporate tax rate denoted as C_Tax, and the difference between home and host corporate tax rates denoted as C_TaxD as principal variables of interest; in this study, corporate income tax presents the statutory income tax. The STR is usually used to the proxy nominal tax burden on business. Its impact on FDI in the findings of Demekas et al. (2005) appear to be significantly negative, while tax incentives seem to have a statistically insignificant effect on FDI. Sato (2012) investigated the impact of tax rate difference (between home and host countries) on FDI and presupposed its effect to be significant and positive, indicating the greater the difference, the higher the FDI inflows. The tax difference between corporate tax rates refers to the variation of corporate tax rates between home and the host country. Sato (2012) indicates that the larger the value of tax difference, the lesser the investment inflows. Investigating bilateral inflows, Bellak et al. (2009) in transition economies also found an adverse effect of tax difference on FDI. We expect an adverse effect of the corporate tax rate on FDI and a positive effect of the tax difference variable on FDI. We use the OECD tax database as a source of corporate tax rate data.

Being aware of the importance of institutional quality, we use two institutional variables to approximate the effect of institutions on FDI inflows. The rule of law takes into account the effectiveness of the judicial system, the enforcement of law and the incidence of crime. Control of corruption considers different corruption indicators. According to Wernick et al. (2009), control of corruption presents the level of exposure of public goods to citizens. Reduced uncertainty in business activities and low presence of corruptive activities tend to encourage FDI inflows. These two variables encompass mutual respect of government and citizens towards institutions which consequently handle their conflicts and interactions (Kraay et al., 1999). Data on corruption and the rule of law are sourced by the World Bank dataset. The variables are expressed as estimates with values between -2.5 and 2.5 . Proximity to 
greater value indicates a strong institutional quality, and therefore the positive and significant coefficients are expected.

Table 1 presents the descriptive statistics of variables. Considering descriptive statistics, we may conclude that all variables depict significant variation over countries and over time (within-group variations and across group variations are not reported here due to space limitations). Importantly, the sample of SEECs integrate countries with substantial differences in tax policy options, though the countries introduced a significant reduction in the corporate tax rate in the period under investigation.

Table 1 | Descriptive statistics

\begin{tabular}{lccccc}
\hline \multicolumn{1}{c}{ Variable } & Obs & Mean & Std.Dev. & Min & Max \\
\hline log FDI & 894 & 5.396645 & 2.095897 & -4.60517 & 9.686512 \\
Log GDP home & 1024 & 27.18089 & 1.339638 & 23.73596 & 28.98383 \\
Log GDP host & 1024 & 23.62447 & 1.213349 & 20.70742 & 26.06168 \\
Distance & 1024 & 1042.864 & 411.7282 & 117.3451 & 1875.018 \\
C_Tax & 1024 & 16.15625 & 6.560866 & 9 & 35 \\
INFL & 1024 & 5.632422 & 11.37443 & -2.167 & 111.959 \\
TradeO & 1016 & 88.80569 & 18.58774 & 24.17033 & 134.5345 \\
LogWage & 832 & 6.187655 & 0.656363 & 4.241327 & 7.336937 \\
CORUPT & 944 & -0.2860335 & 0.2592477 & -1.122741 & 0.2485663 \\
RoLaw & 944 & -0.2779278 & 0.3173644 & -1.343226 & 0.310605 \\
\hline
\end{tabular}

Source: authors

Furthermore, Table 1 (provided in Appendix A1) summarises descriptive statistics of each variable by individual host country included in the sample. The data included in the table is not logged, which allows for a meaningful comparison of key economic indicators across countries. The statistics suggest that there is a considerable cross-country variation across all variables. Specifically, considering the principal variable of interest in this analysis, we note that substantial variation in the levels of the corporate tax rate is observed across and within-host countries over the course of transition. The tax rate ranges from a minimum of $9 \%$ to a maximum of $35 \%$ over the period, with a relatively high standard deviation (overall and within) observed for the period as a whole. The statistics reveal that substantial tax cuts over the period have been introduced, with maximum corporate income tax rate recorded for the end year equivalent to $20 \%$ compared to $35 \%$ recorded in 2000 . These tax cuts may imply a massive reduction in government revenues in the short and medium run, amid they have had no significant impact of MNC decisions on where and how much to invest over the period. This is why the policy trade-offs need to be carefully considered and analysed. The economic rationale behind these tax cuts implies a potential offset for the revenue losses via increased tax base and positive externalities associated with FDI in the long run. These tax cuts and various tax privileges have been considered the main policy tool to promote a more favourable investment climate among SEE countries amid poor economic performance and transition indicators compared to other more advanced transition economies of the CEE 
region. Have these tax cuts led to increases in FDI, and under what conditions do these policy efforts pay off are the principal questions that are being investigated in this paper.

Considering the possible differing host economy conditions which may affect the overall impact of tax policy changes, we carefully consider and take into account the persistent differences across SEE countries in terms of both inward stock of FDI and levels of development, and control for important key transition reform indicators proxied by institutional variables. The statistics suggest a huge across-country variation in FDI data. The FDI average data for the sample as a whole is 1029,7 EUR stock per capita, with a relatively high standard deviation of 2049,5 EUR. The descriptive statistics further suggest considerable cross-country variation in the levels of GDP per capita, with large overall and within variations in the GDP pc data over the period. The GDP pc ranges from a minimum of 870,14 EUR to a maximum of 15,893 EUR across countries observed in the period. Importantly, relatively high overall standard deviation indicated for FDI and GDP pc for some countries compared to the relatively low standard deviation for other countries in the sample reveals substantial differences in the transition reform progress and overall economic performance across SEE countries over the course of transition. For instance, Croatia, Bulgaria and Romania can be considered as countries with dynamic economic growth performance compared to other, supposedly modestly growing countries in the sample. ${ }^{1}$ Table 2 further depicts descriptive statistics of GDP pc difference variable by country. A similar conclusion can be reached when comparing 'within country' descriptive statistics for labour productivity variable, with some countries progressing well and others modestly in terms of productivity growth. Thus, high discrepancies across countries in terms of FDI, GDP pc and labour productivity observed for the end period indicate that the development gap across SEE countries seems persistent. Finally, considering the levels of institutional development across countries, approximated by Rule of Law and Corruption indices in this study, we observe considerable cross-country variation implying huge differences in the patterns of institutional reform.

Overall, the descriptive statistics suggest huge differences in the levels of development and, in particular, the levels of GDP pc, FDI, institutional development and productivity across SEE countries. In view of these differences amid a similar transition reform path, it seems of outmost importance to analyse the effectiveness of the tax policy changes while considering persistent differences in economic performance across SEE countries. Considering past empirical literature, successive corporate income tax cuts may not be optimal policy solutions for the group of countries ranked high in terms of levels of development and labour productivity amid the possible diminishing and conditional marginal effect of tax cuts suggested by the previous literature. What effect tax rate has in the specific context of SEE countries is analysed in sections to follow. Thus, the relatively high standard deviation indices observed for key variables of interest point further to the importance of using logged variables in the models to be estimated econometrically.

\subsection{Method of investigation}

We estimate the regression using Prais-Winsten correlated panels corrected standard errors PSCE method. In this analysis, we deeply consider an appropriate estimation method to obtain robust estimates of individual effects in the presence of heteroscedasticity and serial

\footnotetext{
1 This raw data and descriptive statistics for the inward FDI stock and GDP per capita for host countries is not presented in Tables 1 or 2 . This is an additional calculation of relevant descriptive statistics by the authors.
} 
correlation. We treat the problems of encountered heteroscedasticity and serial correlation with caution. In an attempt to compute heteroscedasticity-robust standard errors and eliminate serial dependence in times series, we follow Plümper et al.'s (2005) recommended technique and use a combination of panel-corrected standard errors with Prais-Winsten transformation (AR1). Specifically, we follow Beck and Katz's (1995) recommended procedure and use panel-corrected standard errors, with corrections for first-order autoregression, and imposition of a common rho for all cross-sections.

\section{Results}

Table 2 reports the results of econometric analysis.

Table 2 | Results of Prais-Winstenregressions

\begin{tabular}{|c|c|c|c|c|c|c|}
\hline & Model 1 & Model 2* & Model 3 & Model 4 & Model 5 & Model 6 \\
\hline GDP home & $\begin{array}{c}0.183^{\star * *} \\
(2.14)\end{array}$ & $\begin{array}{c}0.149^{\star \star \star} \\
(3.38)\end{array}$ & $\begin{array}{l}0.097^{*} \\
(1.69)\end{array}$ & $\begin{array}{c}0.144^{* * *} \\
(2.69)\end{array}$ & $\begin{array}{c}0.140^{\star \star \star} \\
(3.27)\end{array}$ & $\begin{array}{c}0.151^{\star \star \star} \\
(2.52)\end{array}$ \\
\hline GDP host & $\begin{array}{c}1,067^{\star *} \\
(2.14)\end{array}$ & $\begin{array}{c}0.718^{\star \star *} \\
(1.80)\end{array}$ & $\begin{array}{c}1.152^{* * *} \\
(2.48)\end{array}$ & $\begin{array}{l}0.518 \\
(1.44)\end{array}$ & $\begin{array}{c}0.668^{* *} \\
(1.87)\end{array}$ & $\begin{array}{l}1.129^{* \star} \\
(2.52)\end{array}$ \\
\hline Distance & $\begin{array}{c}-0.001^{* * *} \\
(-6.06)\end{array}$ & $\begin{array}{c}-0.001^{\star * *} \\
(-8.31)\end{array}$ & $\begin{array}{c}-0.001^{\star * \star} \\
(-6.20)\end{array}$ & $\begin{array}{c}-0.001^{\star \star \star} \\
(-4.93)\end{array}$ & $\begin{array}{c}-0.001^{* * *} \\
(-4.09)\end{array}$ & $\begin{array}{c}-0.001^{* * *} \\
(-4.71)\end{array}$ \\
\hline Corporate tax & $\begin{array}{c}-0.022^{* \star *} \\
(-6.81)\end{array}$ & $\begin{array}{l}-0.014^{\star *} \\
(-2.23)\end{array}$ & & $\begin{array}{c}-0.013^{* * *} \\
(-5.96)\end{array}$ & $\begin{array}{c}-0.012^{\star \star \star} \\
(-5.94)\end{array}$ & $\begin{array}{c}0.134^{\star * *} \\
(3.20)\end{array}$ \\
\hline $\begin{array}{l}\text { Corporate tax } \\
\text { difference }\end{array}$ & & & $\begin{array}{l}0.022^{\star \star \star} \\
(7.12)\end{array}$ & & & \\
\hline Inflation & $\begin{array}{c}-0.011^{* \star *} \\
(-2.15)\end{array}$ & $\begin{array}{c}-0.011^{\star \star \star} \\
(-5.28)\end{array}$ & $\begin{array}{l}-0.011^{\star *} \\
(-2.20)\end{array}$ & $\begin{array}{c}-0.019^{* * *} \\
(-6.22)\end{array}$ & $\begin{array}{c}-0.016^{\star \star \star} \\
(-5.07)\end{array}$ & $\begin{array}{l}-0.010^{* *} \\
(-2.18)\end{array}$ \\
\hline Trade Openness & $\begin{array}{l}0.009 \\
(1.45)\end{array}$ & $\begin{array}{c}0.009^{\star *} \\
(2.21)\end{array}$ & $\begin{array}{l}0.009 \\
(1.42)\end{array}$ & $\begin{array}{c}0.011^{\star * *} \\
(2.80)\end{array}$ & $\begin{array}{c}0.013^{\star * *} \\
(3.27)\end{array}$ & $\begin{array}{l}0.008 \\
(1.34)\end{array}$ \\
\hline Wage & $\begin{array}{c}3.305^{\star * *} \\
(4.78)\end{array}$ & $\begin{array}{c}1.123^{\star *} \\
(2.00)\end{array}$ & $\begin{array}{c}3.297^{\star * *} \\
(4.86)\end{array}$ & $\begin{array}{c}0.924^{\star *} \\
(2.02)\end{array}$ & $\begin{array}{c}1.249^{* * *} \\
(3.01)\end{array}$ & $\begin{array}{c}3.29^{* * *} \\
(4.79)\end{array}$ \\
\hline GDPpc difference & $\begin{array}{c}0.486^{\star * *} \\
(7.12)\end{array}$ & $\begin{array}{c}0.494^{\star * *} \\
(12.62)\end{array}$ & $\begin{array}{c}0.480^{\star \star \star} \\
(7.90)\end{array}$ & $\begin{array}{c}0.455^{\star \star \star} \\
(10.61)\end{array}$ & $\begin{array}{c}0.445^{\star * *} \\
(9.93)\end{array}$ & $\begin{array}{c}0.746^{\star \star \star} \\
(10.75)\end{array}$ \\
\hline Corruption & & & & $\begin{array}{c}0.780^{\star * *} \\
(3.66)\end{array}$ & & \\
\hline Rule of Law & & & & & $\begin{array}{c}0.564^{\star * *} \\
(2.53)\end{array}$ & \\
\hline Interaction term & & & & & & $\begin{array}{c}-0.015^{\star \star *} \\
(-3.73)\end{array}$ \\
\hline $\begin{array}{l}\text { Hausman test } \\
\text { (Prob>chi2) }\end{array}$ & 0.065 & 0.065 & 0.065 & 0.065 & 0.065 & 0.065 \\
\hline $\begin{array}{l}\text { Wald test for } \\
\text { groupwise } \\
\text { heteroscedasticity } \\
\text { (Prob>chi2) }\end{array}$ & 0.000 & 0.000 & 0.000 & 0.000 & 0.000 & 0.000 \\
\hline $\begin{array}{l}\text { Wooldridge test for } \\
\text { autocorrelation in } \\
\text { panel data } \\
\text { (Prob>F) }\end{array}$ & 0.000 & 0.000 & 0.000 & 0.000 & 0.000 & 0.000 \\
\hline$N$ & 705 & 724 & 705 & 672 & 672 & 705 \\
\hline
\end{tabular}


Note: standard errors are given in brackets (PCSE); all regressions include constant and country dummies (not reported in the table); ${ }^{* \star}$ denotes statistical significance at the level of $1 \% ;{ }^{* *}$ denotes statistical significance at the level of $5 \%$; *denotes statistical significance at the level of $10 \%$; ${ }^{*}$ Regression model with lagged independent variables except Distance and GDPpc difference.

Source: authors

Table 2 presents the results of econometric analysis. Specifically, the table reports OLS fixedeffect panel data estimates with PCSE panel-corrected standard errors, with country-pairspecific effects, and time-specific effects. We applied the standard Hausman test, the results of which are reported in the Table, and indicate that country effects are correlated with explanatory variables. Model 1 presents the results of the baseline gravity equation. Overall, all variables included in the model are of the expected sign and significance. Model 2 presents the results of estimation integrating lagged independent variables to test for the possible biases in the obtained coefficients due to possible endogeneity. Obtained results are robust to different model specifications and to including lagged values to control for possible correlation between the error term and the independent variables.

We find that home size proxied by GDP variable has a significant and positive influence on FDI inflows and that all gravity model variables have the expected sign and significance. The distance variable is negative and significant at $1 \%$, suggesting that the lesser the distance, the higher are the FDI inflows. The closer the countries, the lower transaction and distribution costs are, which attract more FDI in transition countries. The results of estimations reveal a positive and statistically significant coefficient of relative labour cost at a $1 \%$ level of significance, suggesting that a higher labour cost ratio to GDP per capita is associated with higher FDI inflows, depicting higher productivity levels of the workforce, as anticipated. The results show that the inflation rate is statistically significant at $1 \%$, with a negative sign suggesting that the lower the inflation rate, the greater are FDI inflows are, which is in line with previous findings. The positive and significant coefficient of the GDP difference variable indicates that FDI is significantly higher between countries where the relative differences in levels of development are greater, suggesting higher cost advantages of relocation, and thus consistent with the cost efficiency-seeking nature of FDI in SEE countries.

Unexpectedly, trade openness appears insignificant in models estimated, with the exception of estimations using institutional variables (Models 4 and 5) and lagged variables (Model 2). This variable, according to previous studies, plays a very important role in attracting FDI and presents one of the main determinants of FDI. The plausible explanation for the non-stability of the obtained $p$-values may be associated with relatively similar trade rations across SEECs. Regarding institutional variables, it seems that specific institutional characteristics of host economies do affect the increase in FDI flows significantly, and the importance of corruption and the rule of law suggested by this study has been in line with earlier findings on the importance of institutional variables in attracting FDI in transition economies (Bevan \& Estrin, 2004; Estrin \& Uvalic, 2014). This is not surprising given the theoretical underpinnings related to the transaction cost theory of FDI that explain the underlying mechanism of influence associated with corruption and the rule of law. Further, the control of corruption seems not only important in explaining the variations in cross-country FDI inflows in transition context but seems to substitute for the host market size effect, which becomes insignificant 
in Model 4 that integrates this institutional variable. These results could demonstrate that the quality of institutions plays a significant role in multinationals' decision to invest given the similarity of economic and industrial features across the region. Thereby, the quality of institutions and policy improvements can counteract small market size, as well as relatively low productivity in SEE countries.

Essentially, the corporate income tax rate turns out to be statistically significant at $1 \%$, indicating that a lower corporate tax rate positively affects FDI, as a priori expected. In Model 3 , we estimated the impact of tax difference on FDI, which has the same coefficient as the C_Tax variable, and indicate that a rise by $1 \%$ appears to be associated with an increase in FDI inflows by about $2.2 \%$. The estimated semi-elasticity of the C_Tax variable decreases to about 0.014 after controlling for institutional variables (see Models 4 and 5). The obtained results seem in line with the semi-elasticity of the tax variable found in a similar study by Demekas et al. (2005), i.e., $-0.015,-0.008$.

Finally, Model 6 reports the results of the model incorporating the Interaction term. We test for the hypothesis that the impact of corporate income tax is conditional on the level of development proxied by the logGDP per capita. Precisely, the interaction term is measured as C_Tax ${ }^{*} \operatorname{logGDPpc}$ difference, indicating that the lower the difference in the level of development between home and host countries, the lower the importance of tax incentives. The obtained coefficients need to be interpreted cautiously. The obtained coefficient on the C_Tax variable in Model 6 is positive and significant, indicating that higher FDI is associated with higher corporate income tax when GDPdifference is set to 0 , which seems plausible from an economic perspective. The obtained result is in line with previous studies suggesting that tax rate, as well as tax rate differentials, do not exhibit significant influence among countries at a similar level of economic development (Bénassy-Quéré et al., 2000, 2003; Hunady \& Orviska, 2014). Yet, the marginal effect of the Tax variable conditional on the log of GDP per capita difference is given by the obtained coefficients of the interaction term and C_Tax variable. The marginal effect turns out to be positive and significant, suggesting that the impact of tax rate increases with an increase in the differences in logGDP per capita between home and host countries. Put differently, the marginal effect of Corporate income tax diminishes with the increase in the level of development of the host economy, indicating the greater importance of other presumably non-policy factors in attracting FDI in transition economies, as in line with Demekas et al.'s (2005) study. This finding has profound policy implications.

\section{Discussion}

The results of this study render further support to the hypothesis that tax cuts seem a particularly relevant determinant of FDI for the less developed economies, including emerging market and transition economies. This is to say that in addition to the few other relevant studies reviewed in this paper, we bring further empirical evidence to demonstrate that low levels of STR and tax differentials between home and host countries could compensate for the disadvantages in the market potential of less developed economies. These disadvantages may be associated with limited market size and structure, as well as deficient physical infrastructure as suggested by Djankov et al. (2010), and/or production-related material infrastructure as indicated by Bellak et al. (2009), and/or lower levels of economic development supposedly associated with lower levels of technological and innovative 
capabilities of local firms and industries, as indicated by the results of this research. While past empirical research has given a strong indication of the different impact of STR on FDI, i.e. the conditional effect of both statutory tax rate and tax differential in the context of EU countries and CEE countries as new EU member states, we bring new empirical evidence in the specific context of SEE region. Essentially, the obtained results are consistent with the earlier empirical findings.

Further, the results of this study are consistent with Demekas et al.'s (2005) study, which finds that statutory corporate income tax turns to be insignificant for the group of countries above the estimated threshold level of FDI. While the results of Demekas et al.'s study seemingly imply that tax policy may be ineffective in attracting FDI for the higher FDI recipient countries, the results obtained in this study are complementary in that they imply greater importance of tax differentials and tax cuts for countries that are at the lower levels of development.

Furthermore, while past empirical literature suggests the greater importance of relative tax differences as opposed to STR and highlights the significance of incorporating tax rate differentials in models to be estimated (Hansson \& Olofsdotter, 2010), in this study, we find limited (to no) support for the assertation. Specifically, the marginal coefficients obtained for the two variables in this analysis are of similar magnitude and significance. The plausible explanation may be related to the specific context of the host countries included in the sample, which have profoundly lower STR on average compared to the group of highly developed home countries from the EU. Yet, the results of previous studies suggest that tax rate differential is a more important determinant of the decision on how much to invest and that the decision on where to invest is seemingly less sensitive to tax differentials (Hansson \& Olofsdotter, 2010; Razin \& Sadka, 2006). This may be why we do not obtain large variations in the magnitude of the obtained coefficients of the tax variables.

The results of this study shed some light on the importance of both statutory tax rate and tax rate differentials in the specific context of less developed countries of the SEE region. The results are consistent with earlier findings and theoretical propositions that policy and institutional factors could play an important compensatory role in attracting FDI, apart from traditional FDI determinants and amid the specific context of underdeveloped markets and limited industry and technology advances of these economies. More specifically, the results deepen our understanding of when and to what extent tax policy efforts do pay off. Having said this, it is noteworthy that corporate income tax cuts are seemingly more beneficial policy options for countries that rank low in terms of development and other transition indicators. However, further tax cuts may not be a plausible policy option by the number of SEE countries. Put differently, the potential merits of further substantial tax cuts among SEECs may be constrained by the limited fiscal capability of SEECs' governments.

\section{Conclusion}

This study attempts to investigate the impacts of the corporate tax rate in attracting FDI across South-East European countries. Taxation policy seemingly represents the dominant policy instrument in the FDI policy mix across SEE countries that governments use to promote FDI. In this study, we assumed that corporate taxation affects the location decisions of MNEs. Nowadays, all transition countries follow the trend of lowering tax rates because of tax 
competition in order to attract FDI, having their corporate tax rate low, while SEE countries maintain the lowest corporate tax rates in Europe.

Following past empirical research, in this analysis, we first emphasise the inconclusive evidence and vague policy implications related to the obtained mixed results with respect to the tax rate effects in Demekas et al.'s (2005) study. From an FDI policy perspective, the ambiguity is particularly relevant for countries that have introduced substantially low corporate income tax and engaged in forceful tax policy competition, such as is the case of the group of South-East European Countries (SEECs) (see Bellak et al., 2010). We extend this work by focusing on SEE countries in the more recent period, i.e., 2000-2018, the period in which substantial tax cuts have been introduced and the period characterised by the substantial reduction in FDI flows in the wake of financial crises and economic recession. The FDI inflows to the region have not been recovered since. In such a specific contextual framework, we seek to explain whether tax policy efforts pay off. Second, we emphasise the need to study the tax effect on FDI in an integrated framework taking into account a huge range of variables to account for individual country characteristics.

The results of this study are particularly important since they consider the specific context of SEEC, the group of least developed transition economies, that face important policy tradeoffs associated with declining government revenues following provision of diverse fiscal privileges and preferential treatment of foreign companies, including reduction(s) incorporate income tax over the course of transition. Apart from gravity forces which explain a large part of FDI inflows in SEE countries, macroeconomic factors, as well as institutional factors, are suggested to have an influence on MNEs' decision to invest. The influential institutional indicators found in this study include the rule of law and the control of corruption. Apart from these, tax policy seems to be an important determinant of FDI in SEECs, as anticipated. Our results show that the corporate income tax rate turns out to be statistically significant, indicating that a lower corporate tax rate positively affects FDI. According to the obtained results, a $1 \%$ increase in the corporate tax rate would reduce FDI by about $2.2 \%$. We estimated the impact of tax difference on FDI, which rise by $1 \%$ appears to be associated with an increase in FDI inflows by about $2.2 \%$. However, the impact of corporate income tax is conditional on the level of development, suggesting the diminishing marginal effect of STR on FDI with the increase in income per capita.

This result has an important finding that FDI related policies affect FDI and explains the differences in inward FDI stock across SEE countries. However, tax policy effectiveness seems to be conditional on the level of development, possibly depicting differences in market and industrial structures and technological infrastructure of SEE countries. In view of this, we emphasise that the obtained conditional impact STR on FDI imply that different tax policy choices seem particularly relevant for the SEE countries. Although the results suggest that tax cuts positively influence FDI, (possibly) suggesting that policy efforts could compensate for underdeveloped markets and inferior technological infrastructure even among countries that have similar economic structures and have embarked on a similar pattern of transition, potential merits of substantial tax cuts in terms of FDI inflows vary across SEE countries, depending on their level of economic development.

The direct implications of this research for policymakers in SEE include the need to revise and optimise the levels of corporate income tax and incorporate this specific policy instrument in FDI strategies. In particular, the results of this research indicate that tax cuts have been 
more effective in attracting FDI in countries that are at a lower level of technological sophistication. The managers could seek to size the investment opportunity related to possible further corporate income tax cuts in the group of least developed SEE amid the economic rationale for tax policy competition among these countries. Notwithstanding this, given the limited policy scope in terms of lowering corporate income tax, suggested by an earlier study by Bellak et al. (2010), and the obtained results in this study, SEE countries should consider viable alternative policy options and invest in technology and innovationrelated infrastructure and focus more on higher value added FDI, rather than focus solely on cost-related factors as key location determinants in the long run. Substantial policy efforts would be needed to reverse the trend of locational attractiveness principally driven by cost factors and resource abundance to more sophisticated determinants related to knowledge efficiency drivers of FDI.

\section{References}

Alfaro, L., Chanda, A., Kalemli-Ozcan, S., \& Sayek, S. (2004). FDI and economic growth: The role of local financial markets. Journal of International Economics, 64(1), 89-112. https://doi.org/10.1016/S0022-1996(03)00081-3

Beck, N., \& Katz, J. N. (1995). What to do (and not to do) with time-series cross-section data. American Political Science Review, 89(3), 634-647.https://doi.org/10.2307/2082979

Bellak, C., Leibrecht, M., \& Damijan, J. P. (2009). Infrastructure endowment and corporate income taxes as determinants of foreign direct investment in Central and Eastern European countries. The World Economy, 32(2), 267-290.https://doi.org/10.1111/j.1467-9701.2008.01144.x

Bellak, C., Leibrecht, M., \& Liebensteiner, M. (2010). Attracting foreign direct investment: the public policy scope for South East European countries. Eastern Journal of European Studies, 1(2), 37-53.

Bénassy-Quéré, A., Fontagné, L., \& Lahrèche-Révil, A. (2000). Foreign direct investment and the prospects for tax co-ordination in Europe. Working Papers No. 2000-06. CEPII Research Center.http://citeseerx.ist.psu.edu/viewdoc/download?doi=10.1.1.556.396\&rep=rep1\&type=pdf

Bénassy-Quéré, A., Fontagné, L., \& Lahrèche-Révil, A. (2003). Tax competition and foreign direct investment. Working Papers No. 2003-17. CEPII Research Center. http://www.cepii.fr/PDF_PUB/wp/2003/wp2003-17.pdf

Bénassy-Quéré, A., Fontagné, L., \& Lahrèche-Révil, A. (2005). How does FDI react to corporate taxation? International Tax and Public Finance, 12(5), 583-603.https://doi.org/10.1007/s10797005-2652-4

Bevan, A. A., \& Estrin, S. (2004). The determinants of foreign direct investment into European transition economies. Journal of Comparative Economics, 32(4), 775787.https://doi.org/10.1016/j.jce.2004.08.006

Bijsterbosch, M., \& Kolasa, M. (2010). FDI and productivity convergence in Central and Eastern Europe: an industry-level investigation. Review of World Economics, 145(4), 689-712.

Borensztein, E., De Gregorio, J., \& Lee, J.-W. (1998). How does foreign direct investment affect economic growth? Journal of International Economics, 45(1), 115-135. https://doi.org/10.1016/S0022-1996(97)00033-0

Brenton, P., Di Mauro, F., \& Lücke, M. (1999). Economic integration and FDI: An empirical analysis of foreign investment in the EU and in Central and Eastern Europe.Empirica,26(2), 95121.https://doi.org/10.1023/A:1007006429600 
Carstensen, K., \& Toubal, F. (2004). Foreign direct investment in Central and Eastern European countries: A dynamic panel analysis. Journal of Comparative Economics,32(1), 3-22. https://doi.org/10.1016/j.jce.2003.11.001

Damijan, J. P., Knell, M., Majcen, B., \& Rojec, M. (2003). The role of FDI, R\&D accumulation and trade in transferring technology to transition countries: evidence from firm panel data for eight transition countries. Economic systems, 27(2), 189-204.

Demekas, G. D., Horváth, B., Ribakova, E., \& Wu, Y. (2005). Foreign Direct Investment in Southeastern Europe: How (and How Much) Can Policies Help? IMF Working Paper, European Department, WP/05/110.

Demekas, D. G., Horváth, B., Ribakova, E., \& Wu, Y. (2007). Foreign direct investment in European transition economies - The role of policies. Journal of comparative economics, 35(2), 369-386.

De Mello, L. R. (1999). Foreign direct investment-led growth: Evidence from time series and panel data. Oxford Economic Papers,51(1), 133-151. https://doi.org/10.1093/oep/51.1.133

Djankov, S., Ganser, T., McLiesh, C., Ramalho, R., \& Shleifer, A. (2010). The effect of corporate taxes on investment and entrepreneurship. American Economic Journal: Macroeconomics, 2(3), 31 64. https://doi.org/10.1257/mac.2.3.31

Dunning, J. H. (1988). The eclectic paradigm of international production: A restatement and some possible extensions. Journal of International Business Studies, 19(1), 1-31. https://doi.org/10.1057/palgrave.jibs.8490372

Dunning, J. H. (1993). Multinational enterprises and the global economy. Addison-Wesley.

Estrin, S., \& Uvalic, M. (2014). FDI into transition economies: Are the Balkans different? Economics of Transition, 22(2), 281-312.https://doi.org/10.1111/ecot.12040

Hansson, A.., \& Olofsdotter, K. (2010). Tax differences and foreign direct investment in the EU27. Lund University Working Papers No. $3 . \quad$ Lund University. http://project.nek.lu.se/publications/workpap/Papers/WP10_3.pdf

Heimberger, P. (2021). Corporate tax competition: A meta-analysis. European Journal of Political Economy.https://doi.org/10.1016/j.ejpoleco.2021.102002

Hunady, J., \& Orviska, M. (2014). Determinants of foreign direct investment in EU countries-do corporate taxes really matter?.Procedia Economics and Finance, 12, 243-250.

Hyman, D. N. (2014). Public finance: A contemporary application of theory to policy (11th ed.).Cengage Learning.

Kraay, A., Zoido-Lobatón, P., \& Kaufmann, D. (1999). Aggregating governance indicators. World Bank Group.https://doi.org/10.1596/1813-9450-2195

Kersan-Škabić, I. (2015). The importance of corporate taxation for FDI attractiveness of southeast European countries. Panoeconomicus, 62(1), 105-122.https://doi.org/10.2298/PAN1501105K

Merz, J., Overesch, M., \& Wamser, G. (2017). The location of financial sector FDI: Tax and regulation policy. Journal of Banking \& Finance, 78, 14-26. https://doi.org/10.1016/j.jbankfin.2017.01.001

OECD. (2016a). Corporate income tax rates [Data set]. https://doi.org/10.1787/7cde787f-en

OECD. (2016b). Competitiveness in South East Europe: A Policy Outlook, Competitiveness and Private Sector Development, OECD Publishing, Paris.

Plümper, T., Troeger, V. E., \& Manow, P. (2005). Panel data analysis in comparative politics: Linking method to theory. European Journal of Political Research, 44(2), 327-354. 
Rădulescu, M., \& Druica, E. (2014). The impact of fiscal policy on foreign direct investments. Empiric evidence from Romania. Economic research-Ekonomskaistraživanja, 27(1), 86106.https://doi.org/10.1080/1331677X.2014.947133

Razin, A., \& Sadka, E. (2006). Vying for Foreign Direct Investment: A EU-type Model of Tax Competition, NBER Working Papers 11991, National Bureau of Economic Research, Inc.

Resmini, L. (2000). The determinants of foreign direct investment in the CEECs: New evidence from sectoral patterns. Economics of Transition and Institutional Change, 8(3), 665689.https://doi.org/10.1111/1468-0351.00060

Sato, T. (2012). Empirical analysis of corporate tax and foreign direct investment. Public Policy Review,8(1), 1-20.

Singhania, M., \& Saini, N. (2018). Determinants of FPI in developed and developing countries. Global Business Review, 19(1), 187-213.https://doi.org/10.1177/0972150917713280

Silajdžić, S., \& Mehić, E. (2012). How important are institutions in promoting foreign direct investment in transition economies? Evidence from Southeast European Economies. ICES 2012-Beyond the Economic Crisis: Lessons Learned and Challenges Ahead (pp. 746-766). University of Sarajevo, School of Economics and Business

Silajdžić, S., \& Mehić, E. (2016). Absorptive capabilities, FDI, and economic growth in transition economies. Emerging Markets Finance and Trade, 52(4), 904922.https://doi.org/10.1080/1540496X.2015.1056000

Wernick, D. A., Haar, J., \& Singh, S. (2009). Do governing institutions affect foreign direct investment inflows? New evidence from emerging economies. International Journal of Economics and Business Research, 1(3), 317-332.https://doi.org/10.1504/IJEBR.2009.024307

Wolff, G. B. (2007). Foreign direct investment in the enlarged EU: Do taxes matter and to what extent? Open Economies Review, 18(3), 327-346.https://doi.org/10.1007/s11079-007-9041-9

The research paper passed the review process. | Received: December 29, 2020; Revised: March 8, 2021; Accepted: April 7, 2021; Pre-published online: August 16, 2021; Published in the regular issue: March 16, 2022. 


\section{Appendix}

Table A1 | Descriptive statistics

\begin{tabular}{|c|c|c|c|c|c|c|c|c|c|}
\hline Variable & & Albania & $\begin{array}{l}\text { Bosnia and } \\
\text { Herzegovina }\end{array}$ & Bulgaria & Croatia & Macedonia & Montenegro & Romania & Serbia \\
\hline \multirow[t]{5}{*}{ FDI } & Obs & 102 & 104 & 128 & 126 & 128 & 60 & 125 & 121 \\
\hline & Mean & 153.74 & 272.33 & 1361.48 & 1464.57 & 160.89 & 139.48 & 3307.78 & 622.37 \\
\hline & Std. dev. & 165.45 & 308.32 & 1939.40 & 1880.97 & 191.76 & 134 & 3770.50 & 715.56 \\
\hline & Min & 0.61 & 11.01 & 0.29 & 0.01 & 0.29 & 4.07 & 6.2 & 0.03 \\
\hline & Max & 687.65 & 1400.94 & 7326.20 & 10203.49 & 959.98 & 520.84 & 16099 & 3101.07 \\
\hline \multirow[t]{5}{*}{ GDP home } & Obs & 128 & 128 & 128 & 128 & 128 & 128 & 128 & 128 \\
\hline & Mean & $1.18 \mathrm{e}+12$ & $1.18 \mathrm{e}+12$ & $1.18 e+12$ & $118 e+12$ & $1.18 \mathrm{e}+12$ & $1.18 \mathrm{e}+12$ & $1.18 \mathrm{e}+12$ & $1.18 e+12$ \\
\hline & Std. dev. & $1.09 e+12$ & $1.09 e+12$ & $1.09 e+12$ & $1.09 e+12$ & $1.09 e+12$ & $1.09 e+12$ & $1.09 e+12$ & $1.09 e+12$ \\
\hline & Min & $2.03 e+10$ & $2.03 e+10$ & $2.03 e+10$ & $2.03 e+10$ & $2.03 e+10$ & $2.03 e+10$ & $2.03 e+10$ & $2.03 e+10$ \\
\hline & Max & $3.87 e+12$ & $3.87 e+12$ & $3.87 e+12$ & $3.87 e+12$ & $3.87 e+12$ & $3.87 e+12$ & $3.87 e+12$ & $3.87 e+12$ \\
\hline \multirow[t]{5}{*}{ GDP host } & Obs & 128 & 128 & 128 & 128 & 128 & 128 & 128 & 128 \\
\hline & Mean & $9.54 \mathrm{e}+09$ & $1.37 e+10$ & $3.92 e+10$ & $4.87 e+10$ & $7.80 e+09$ & $3.14 e+09$ & $1.33 e+11$ & $3.27 e+10$ \\
\hline & Std. dev. & $3.41 e+09$ & $4.96 e+09$ & $1.62 \mathrm{e}+10$ & $1.47 e+10$ & $2.64 \mathrm{e}+09$ & $1.32 e+09$ & $6.08 e+10$ & $1.29 e+10$ \\
\hline & Min & $3.63 e+09$ & $5.51 e+09$ & $1.31 e+10$ & $2.18 e+10$ & $3.071 e+09$ & $9.84 e+08$ & $3.74 \mathrm{e}+10$ & $6.54 e+09$ \\
\hline & $\operatorname{Max}$ & $1.33 e+10$ & $1.91 \mathrm{e}+10$ & $5.69 e+10$ & $7.05 e+10$ & $1.13 e+10$ & $4.59 \mathrm{e}+09$ & $2.08 \mathrm{e}+11$ & $4.93 e+10$ \\
\hline \multirow[t]{5}{*}{ Distance } & Obs & 128 & 128 & 128 & 128 & 128 & 128 & 128 & 128 \\
\hline & Mean & 1123.36 & 923.98 & 1191.12 & 753.95 & 1146.05 & 970.17 & 1264.10 & 970.17 \\
\hline & Std. dev. & 376.90 & 376.40 & 383.33 & 435.77 & 374.01 & 352.83 & 397.82 & 352.83 \\
\hline & Min & 611.76 & 394.74 & 795.24 & 117.34 & 717.58 & 488.03 & 746.41 & 488.03 \\
\hline & Max & 1664.81 & 1375.38 & 1760.70 & 1520.35 & 1694.94 & 1449.71 & 1875.01 & 1449.71 \\
\hline \multirow{5}{*}{$\begin{array}{l}\text { Corporate } \\
\text { tax }\end{array}$} & Obs & 128 & 128 & 128 & 128 & 128 & 128 & 128 & 128 \\
\hline & Mean & 7.41 & 20 & 13.93 & 20.93 & 12.31 & 13.12 & 18.81 & 12.93 \\
\hline & Std. dev. & 17.18 & 10.03 & 5.17 & 3.64 & 2.42 & 5.34 & 4.18 & 3.41 \\
\hline & Min & 10 & 10 & 10 & 20 & 10 & 9 & 16 & 10 \\
\hline & Max & 30 & 30 & 25 & 35 & 15 & 20 & 25 & 20 \\
\hline \multirow{5}{*}{$\begin{array}{l}\text { Corporate } \\
\text { tax } \\
\text { difference }\end{array}$} & Obs & 128 & 128 & 128 & 128 & 128 & 128 & 128 & 128 \\
\hline & Mean & 7.41 & 4.60 & 10.66 & 3.66 & 12.17 & 12.10 & 5.76 & 11.66 \\
\hline & Std. dev. & 8.94 & 10.64 & 8,17 & 8.54 & 7.82 & 8.15 & 8.01 & 8.38 \\
\hline & Min & -21.5 & -21.5 & -16.5 & -26.5 & -6.5 & -11.5 & -16.5 & -11.5 \\
\hline & Max & 23.33 & 23.33 & 23.33 & 16 & 25 & 24.33 & 17.33 & 23.33 \\
\hline \multirow[t]{5}{*}{ Inflation } & Obs & 128 & 128 & 128 & 128 & 128 & 128 & 128 & 128 \\
\hline & Mean & 7.41 & 1.91 & 4.30 & 2.41 & 2.24 & 6.50 & 10.03 & 15.10 \\
\hline & Std. dev. & 8.94 & 2.44 & 3.82 & 1.75 & 2.38 & 8.18 & 10.81 & 25.87 \\
\hline & Min & -21.5 & -1.41 & -1.96 & -0.46 & -2.16 & -0.30 & -0.94 & 1.55 \\
\hline & Max & 23,33 & 7 & 11.57 & 5.78 & 6.15 & 27.86 & 40.71 & 111.59 \\
\hline \multirow[t]{5}{*}{ Openness } & Obs & 128 & 120 & 128 & 128 & 128 & 128 & 128 & 128 \\
\hline & Mean & 75.17 & 93.83 & 107.12 & 83.50 & 94.54 & 105.11 & 75.34 & 76.10 \\
\hline & Std. dev. & 10.95 & 11.02 & 20.88 & 5.44 & 15.94 & 14.60 & 5.72 & 18.36 \\
\hline & Min & 55.92 & 73.80 & 75.46 & 72.76 & 71.06 & 77.59 & 61.15 & 24.17 \\
\hline & Max & 90.76 & 113.45 & 134.53 & 96.01 & 113.32 & 133.47 & 82.82 & 103.1 \\
\hline \multirow{5}{*}{$\begin{array}{l}\text { Wage } \\
\text { (Productivity) }\end{array}$} & Obs & 112 & 128 & 64 & 120 & 112 & 88 & 120 & 88 \\
\hline & Mean & 0.08 & 0.17 & 0.06 & 0.10 & 0.14 & 0.12 & 0.07 & 0.10 \\
\hline & Std. dev. & 0.01 & 0.01 & 0.001 & 0.01 & 0.01 & 0.01 & 0.003 & 0.01 \\
\hline & Min & 0.07 & 0.15 & 0.05 & 0.09 & 0.12 & 0.10 & 0.06 & 0.07 \\
\hline & Max & 0.09 & 0.18 & 0.07 & 0.11 & 0.15 & 0.14 & 0.08 & 0.12 \\
\hline \multirow{5}{*}{$\begin{array}{l}\text { GDPpc } \\
\text { difference }\end{array}$} & Obs & 128 & 128 & 128 & 128 & 128 & 128 & 127 & 128 \\
\hline & Mean & 32180.93 & 31850.36 & 30159.42 & 24265.74 & 31628.33 & 30330.46 & 28888.89 & 30941.01 \\
\hline & Std. dev. & 17752.76 & 17729.33 & 17376.36 & 17043.72 & 17742.7 & 17431.37 & 17200.58 & 17529.13 \\
\hline & Min & 1726.89 & 1540.87 & 1291.40 & -5533.19 & 1218.85 & 1144.23 & 157.10 & 1418.99 \\
\hline & Max & 83564.80 & 83141.83 & 80252.57 & 73460.43 & 82922.65 & 80683.87 & 78802.33 & 81579.32 \\
\hline \multirow[t]{5}{*}{ Corruption } & Obs & 120 & 120 & 120 & 120 & 120 & 104 & 120 & 120 \\
\hline & Mean & -0.66 & -0.32 & -0.18 & 0.06 & -0.28 & -0.26 & -0.22 & -0.40 \\
\hline & Std. dev. & 0.12 & 0.06 & 0.12 & $: 12$ & 0.28 & 0.16 & 0.10 & 0.25 \\
\hline & Min & -0.85 & -0.48 & -0.31 & -0.20 & -0.88 & -0.57 & -0.47 & -1.12 \\
\hline & Max & -0.44 & -0.19 & 0.09 & 0.24 & 0.09 & -0.01 & -0.04 & -0.19 \\
\hline \multirow[t]{5}{*}{ Rule of Law } & Obs & 120 & 120 & 120 & 120 & 120 & 104 & 120 & 120 \\
\hline & Mean & -0.66 & -0.42 & -0.13 & 0.10 & -0.35 & -0.10 & -0.04 & -0.57 \\
\hline & Std. dev. & 0.23 & 0.16 & 0.04 & 0.12 & 0.17 & 0.16 & 0.13 & 0.33 \\
\hline & Min & -1.24 & -0.68 & -0.22 & -0.17 & -0.65 & -0.35 & -0.26 & -1.34 \\
\hline & Max & -0.35 & -0.15 & -0.07 & 0.31 & -0.03 & 0.06 & 0.15 & -0.09 \\
\hline
\end{tabular}

Source: authors 